\section{IMPACTO DO QUADRUPLE AIM NA REDUÇÃO DO BURNOUT EM PROFISSIONAIS DE SAÚDE: UMA REVISÃO DE LITERATURA}

Autores: Medeiros, L.M. A.; Luca, F.R.; Félix, A.P.

Instituto Brasileiro de Controle do Câncer (IBCC) - SP

\section{Introdução}

A proposta do Quadruple Aim adiciona ao conceito de valor de saúde um olhar voltado a experiência de prestação de cuidado com qualidade, satisfação do paciente e custos reduzidos.

\section{Objetivo}

Compreender como o Quadruple Aim contribui na qualidade da assistência e segurança dos serviços, reduzindo o grau de burnout dos profissionais de saúde.

\section{Metodologia}

Revisão de literatura, relacionando Quadruple Aim e burnout em profissionais de saúde. Encontramos 64 artigos, tendo sido excluídos 60 por se tratarem de produções duplicadas, assunto principal não relacionar-se com a pesquisa.

\section{Resultados}

As análises dos artigos sinalizam a importância de trabalhar o Quadruple Aim na área da saúde, com o aumento da prevalência do burnout, gerando consequências para os profissionais e pacientes. A insatisfação aumenta a probabilidade de menor empatia, comportamentos não

\section{Considerações Finais}

0 quarto objetivo surge com o intuito de valorizar o profissional de saúde, diminuindo a possibilidade de realização de erros, aumentando a segurança do cuidado e a satisfação do cliente interno. Devem-se priorizar o bem-estar para os profissionais de saúde, favorecendo uma cultura de segurança, satisfação dos profissionais e engajamento destes na Instituição.

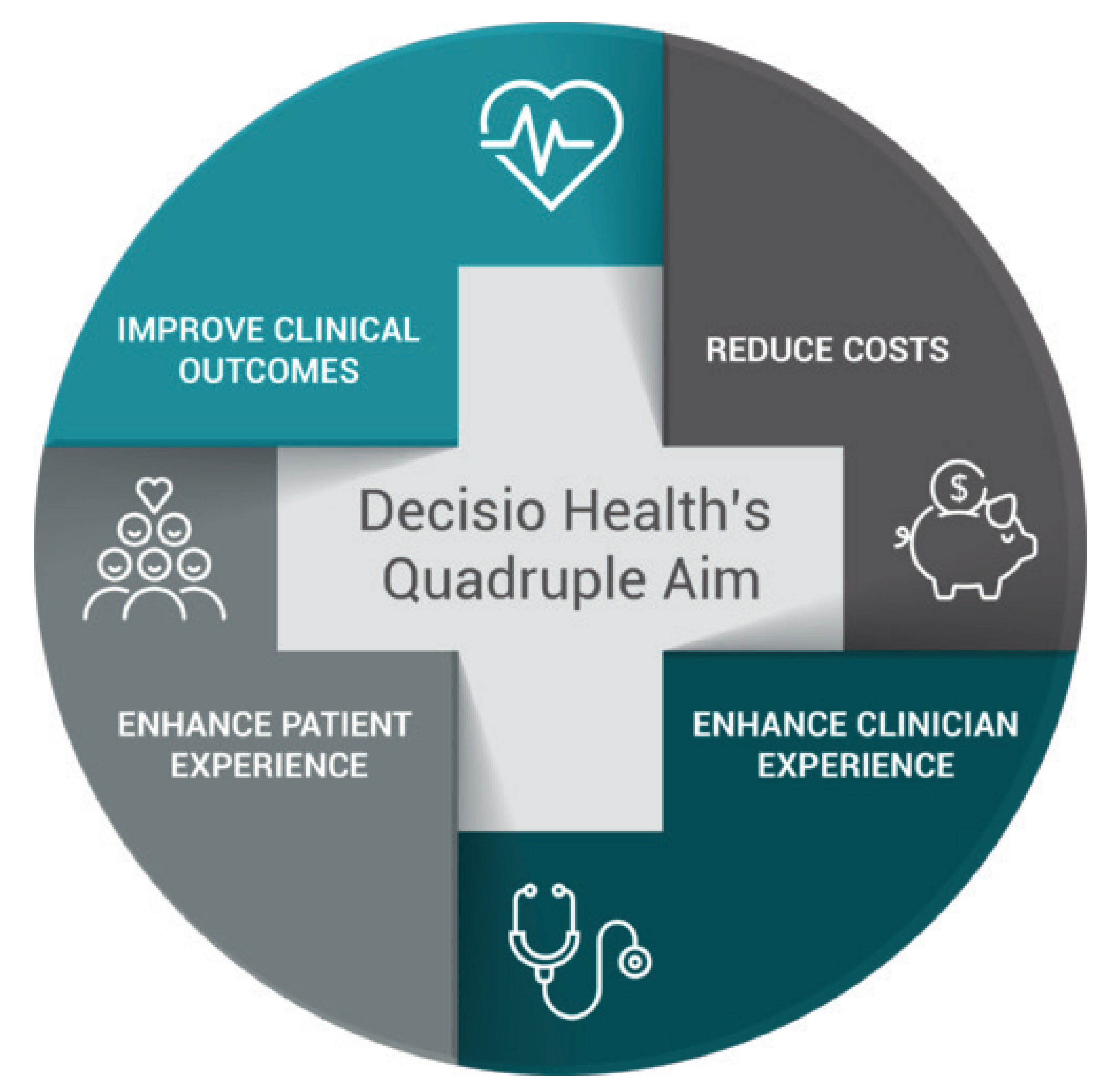

\section{Referências bibliográficas}

1. Bodenheimer, T., SINSKY, C. Triple to Quadruple Aim: Care of the Patient Requires Care of the Provider. Annals of Family Medicine, San Francisco, v. 12, n. 06, p. 573-576, nov./dez. 2014

2. Barnett, K. A. G. In Pursuit of the Fourth Aim in Health Care: The Joy of Practice. Medical Clinics of North America, [S.L], v. 101, n. 5, p. 1031-1040, set. 2017.

3. Ejnes Y. De. Empowering trainees to aim for physician wellness. J Grad Med Educ. 2016;8(5):775-776. [Abstract] [Google Scholar].

4. Epperson, W. J. et al. Provider Burnout and Patient Engagement: The Quadruple and Quintuple Aims. The Journal of Medical Practice Management, South Carolina, v. 31, n. 6, p. 359-363, mai.jjun. 2016. 